\title{
Males of Nectarinella Bequaert (Hymenoptera, Vespidae, Polistinae)
}

\author{
James M. Carpenter ${ }^{1} \&$ Sidnei Mateus ${ }^{2}$
}

\begin{abstract}
${ }^{1}$ Division of Invertebrate Zoology, American Museum of Natural History. Central Park West at $79^{\text {th }}$ Street, New York, NY 10024 , U. S. A. E-mail: carpente@amnh.org

${ }^{2}$ Departamento de Biologia, Universidade de São Paulo. Av. Bandeirantes 3900, 140140-901 Ribeirão Preto-SP, Brazil.

E-mail: sidmateu@usp.br
\end{abstract}

\begin{abstract}
Resumo. Os machos das duas espécies de vespas sociais do gênero Nectarinella Bequaert, $N$. xavantinensis Mateus \& Noll e N. championi (Dover), são descritos e suas genitálias ilustradas. São feitas comparações com espécies de gêneros estreitamente relacionados, Chartergellus, Leipomeles, Marimbonda, Parachartergus e Pseudopolybia.

Palavras-Chave. Epiponini; genitalia; Polistinae; taxonomia; Vespidae.

Aвstract. The males of both species of the paper wasp genus Nectarinella Bequaert, $N$. xavantinensis Mateus \& Noll and $N$. championi (Dover), are described, and the genitalia illustrated. These are compared to species in the closely related genera Chartergellus, Leipomeles, Marimbonda, Parachartergus and Pseudopolybia.
\end{abstract}

Keywords. Epiponini; male genitalia; Polistinae; taxonomy; Vespidae.

Nectarinella was described by BEQUAERT (1938) as a subgenus of Chartergus, monotypic for the species Nectarina championi Dover, 1925. That species was described from Panama, based on female specimens only. It was subsequently recorded from Costa Rica by Sкuтch (1971), who described the nest, which is astelocyttarus, that is with the comb lacking a petiole and built directly on the substrate and covered with an envelope. The nest is remarkable for having numerous fine paper pillars tipped with a sticky secretion on the envelope and surrounding it like a palisade, which evidently function as a guard against ants (SkUtch 1971:274; Schremmer 1977). SCHREMMER (1977) treated Nectarinella as a genus, and recorded championi from Colombia. In the monograph of New World paper wasps by Richards (1978) Nectarinella remained monotypic, and the males unknown. Recently, MAteus \& NolL (1998) described a second species, N. xavantinensis, from Brazil (Mato Grosso); it has a similar nest architecture, with sticky ant guards. Males of that species were unknown, but recently Mateus \& Noll collected specimens of that sex.

Males of relatively few species of Polistinae have been adequately described. The descriptions of males in the monograph by RICHARDS (1978) refer mostly to characters that show the same sexual dimorphism throughout Polistinae, e. g. antennae, clypeus, tempora, metasoma, pilosity and coloration. The male genitalia were scarcely discussed, RICHARDS (1978: 5) summarizing an unpublished survey of polistine genera by Vreugdenhil and van der Vecht for just three characters: whether or not the aedeagus was serrate beneath, whether or not the parameral spines are hairy, and relatively anterior or posterior placement of the ventral process of the aedeagus. Based on these characters, the polistine genera were stated to fall into two groups. Nectarinella was the only genus for which males were unknown, but it was predicted to fall in group 1, with the aedeagus serrate, parameral spines hairy, and ventral process of aedeagus anterior and attached to the basal apodeme.

We here describe the male of $N$. xavantinensis, and also the male of $N$. championi, and illustrate their genitalia. For comparison, we also provide illustrations of species of the closely related genera (CARPENTER 1991; Wenzel \& CARPENTER 1994) Chartergellus Bequaert, 1938, Leipomeles Moebius, 1856, Marimbonda Richards, 1978, Parachartergus Ihering, 1904 and Pseudopolybia Dalla Torre, 1894.

\section{MATERIALS AND METHODS}

Male specimens of N. xavantinensis were collected in Brazil: Mato Grosso, Prefeitura Mutum do Novo Mutum, 17 September 2002 (S. Mateus \& F. B. Noll), Nest no. 37. Male specimens of $N$. championi were collected in Costa Rica: Rio Grande, 6 km E Atenas, 700 m, 8 December 1990 (J. M. Carpenter \& J. W. Wenzel), Nest no. 901208-1. Two males of each species were relaxed and the genital capsule extracted, cleared slightly in warm lactophenol, and examined under glycerin. A male specimen of Chartergellus punctatior from Peru: Oxapampa, 1600 m, 1940 (Weyrauch), borrowed from the U. S. National Museum, was also dissected. The figures of the male genitalia of species of Parachartergus, Leipomeles and Marimbonda (Figs. 4-9) were given to Carpenter by the late J. van der Vecht as part of parcel of unpublished figures of polistine genitalia, drawn as part of the unpublished survey mentioned above. We are pleased to be able to take this opportunity to publish more of van der Vecht's work.

\section{RESULTS}

These two species differ from one another as summarized for the females by Mateus \& Noll (1998). The outstanding 
differences may be shown in a key, which has not previously been published:

1. Frons elevated above antennae, forming a V-shaped protuberance; humeri produced forward in acute angle in dorsal view; clypeus wider than high; metasomal ground color brownish. BRAZIL: Mato Grosso ......... . N. xavantinensis Mateus \& Noll

Frons flat above antennae; humeri little produced in dorsal view; clypeus about as wide as high; metasomal ground-color ochraceous. COSTA RICA, PANAMA, COLOMBIA .................................. championi (Dover)

In both species of Nectarinella the males, unlike the females, have the clypeus covered with dense silvery pubescence, the tempora narrower, and the terminal metasomal sternum flatter, as well as the antenna with one more article and the metasoma one more visible segment. The males are not notably paler than the females.

The genitalia of $N$. xavantinensis are illustrated in Fig. 1, and of $N$. championi in Fig. 2. The other genera are illustrated in Figs. 3-9.

In comparison to each other, the genitalia of the two species of Nectarinella show few outstanding differences: both the digitus and cuspis are somewhat more robust in $N$. xavantinensis, and the paramere is more strongly narrowed in its basal angle (cf. Figs. 1 and 2). With respect to the three characters mentioned by RicHARDS (1978: 5), both species have the aedeagus serrate beneath, the parameral spine lacking long hairs, and the ventral process of the aedeagus could be said to be "more anterior [i. e., towards the head, that is basal in Figs. 1-2] and more or less attached to the basal apodeme." Two of these characters correspond to group 1 of RICHARDS (1978), but the parameral spines lacking long hairs does not. However, although Chartergellus, Leipomeles, Parachartergus and Pseudopolybia were stated to belong to the group with long hairs, as seen in Figs. 3-4, 6-7 and 8-9, this state is only found in Pseudopolybia. Richards (1978: 5) qualified the group description for Parachartergus, saying "Parameral spines usually with long hairs but at least (Parachartergus) some short ones," which is true for the species illustrated in Figs. 6-7. But even Richards' (1978: fig. 88a) own figure of the genitalia of Chartergellus does not show long hairs on the paramere. On the other hand, Leipomeles and Marimbonda were both placed by RICHARDS (1978: 5) in group 2, with the "Aedeagus very rarely serrate beneath and then only on one edge of the ventral process (Leipomeles)." Leipomeles was thus placed in both groups, although the placement in group 2 may have been some sort of typographical error, for as Fig. 4 shows the aedeagus is serrate beneath on both edges. This is also true for Marimbonda, however. Moreover, the ventral process cannot be said to be "more posterior, attached to a ventral extension of the posterior expansion rather than to the apodemes" in either Leipomeles or Marimbonda. Thus, two out of three characters would argue for placement of both genera in group
1 of Richards. But in view of the contradiction of the state of the hairs on the parameral spine for all of these genera aside from Pseudopolybia, it seems better to abandon groupings based on the combination of character states cited by Richards.

The six genera discussed in this paper are supported as a monophyletic group by shared possession of a stout, recurved bristle on the third labial palpomere (CARPENTER 1991). The remaining genera aside from Pseudopolybia are supported as a group by reduction in labial palpomere number, from four to three. The four genera aside from Parachartergus and Pseudopolybia are supported as a group by reduction in the maxillary palpomere number, from six to five. Leipomeles and Marimbonda are supported as sister-groups by the similar form of the first metasomal segment (conically petiolate), while a possible synapomorphy in nest architecture is the central furrow built in the lines of construction of the envelope (WeNZEL \& CARPENTER 1994). Chartergellus and Nectarinella are supported as sister-groups by loss of the occipital carina - a state also found in Pseudopolybia (as well as some other polistine genera). With that framework in mind, we turn to consideration of the similarities illustrated in the genitalia studied here.

Pseudopolybia (Figs. 8-9) is the only genus with long hairs on the parameral spine. If that is in fact the primitive condition for a larger group of genera, then loss of such hairs supports the grouping of the five genera that have lost the fourth labial palpomere. Study of additional genera besides those considered here is required to settle this. All of these genera have the aedeagus serrate beneath, which is clearly primitive for a large number of polistine genera. Placement of the ventral process of the aedeagus as such does not seem offer evidence on phylogenetic relationship in the genera considered here, but shape may: the very narrow, reduced, almost hooking shape in most of these genera (Figs. 1-2, 4-7) contrasts with the short angular process in Pseudopolybia (Figs. 8-9) - but this is also the condition in Chartergellus (Fig. 3), and see Richards (1978: figs. 88-90). If the narrow reduced shape is apomorphic, then Chartergellus either shows a reversal or is misplaced.

Additional characters to those previously considered are evident. All six of these genera show a basal angular process on the digitus (Figs. 1-9), which may support them as a monophyletic group; the condition is not general in Polistinae. This process is least well developed in the Chartergellus punctatior Richards, 1978 studied here, and may be variable in the genus (see RichARDS 1978: fig. 88c for C. communis Richards and $89 \mathrm{c}$ for $C$. atectus Richards; but cf. also Fig. 3 with fig. 90c for $C$. punctatior). The shape of the digitus is otherwise rather variable in these genera: it is apically pointed in Nectarinella (Figs. 1-2), Chartergellus (Fig. 3) and Pseudopolybia compressa Saussure, 1854 (Fig. 8); it is more rounded in the remaining taxa. Based on the relationships mentioned above, this is not a readily interpretable pattern. In the two species of Nectarinella (Figs. 1-2), the cuspis appears apically shorter than the remaining genera (Figs. 3-9), which may be apomorphic. Most of these genera show a very acute 

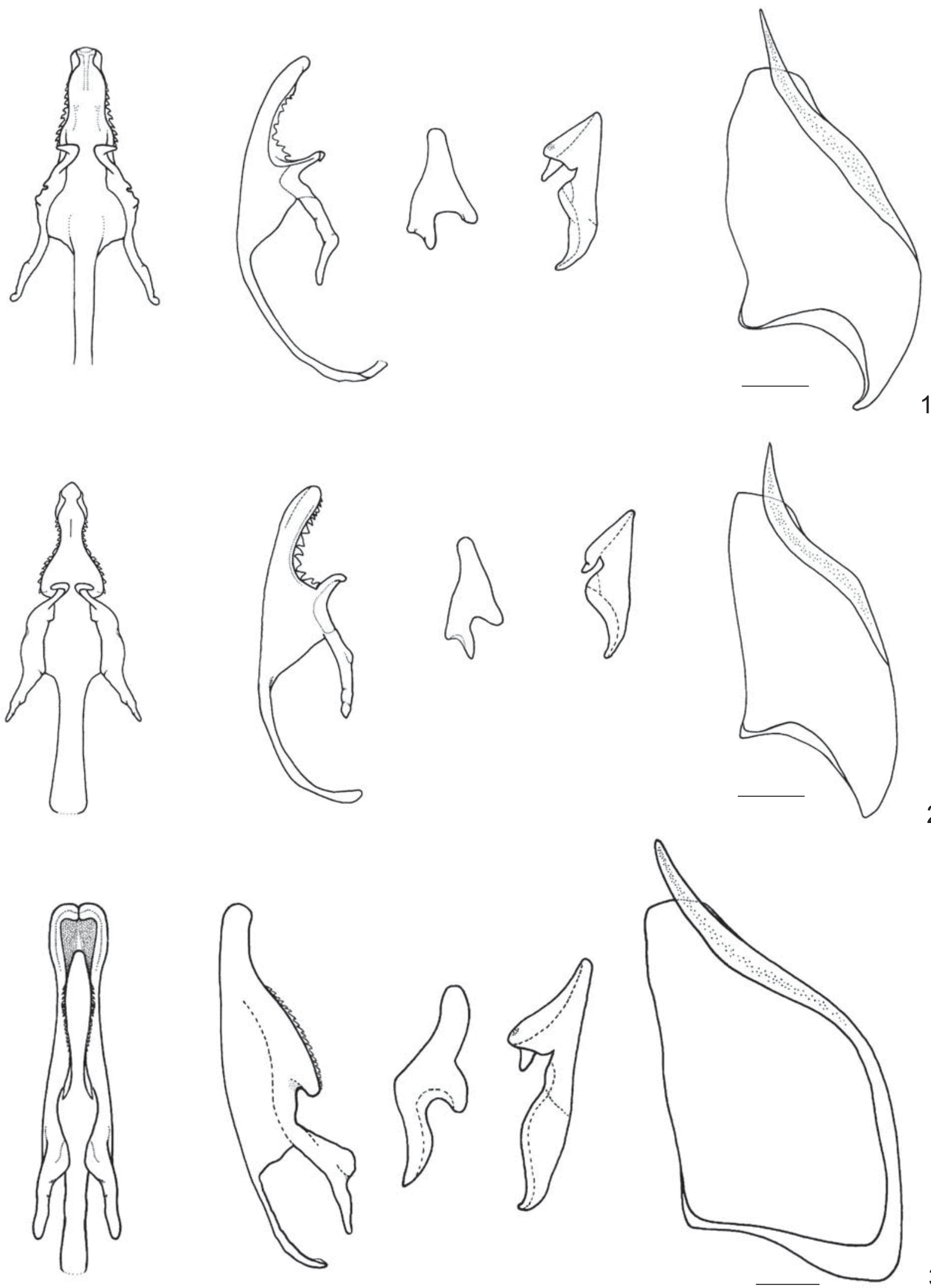

2
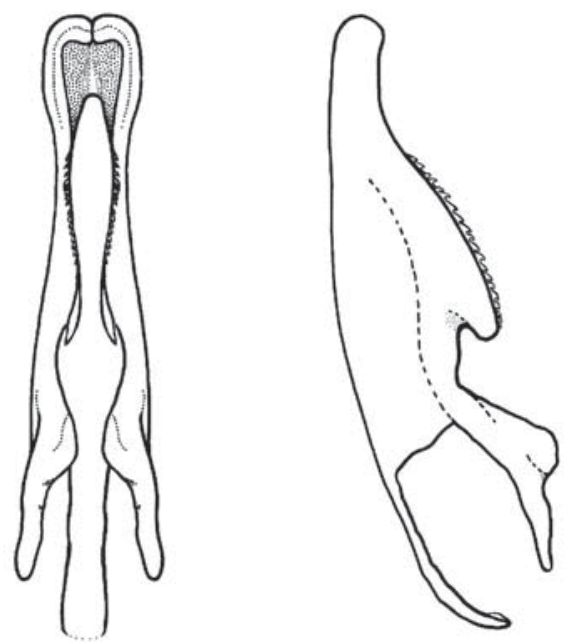

Figs. 1-3. 1, male genitalia of Nectarinella xavantinensis Mateus \& Noll. From left to right, aedeagus in ventral view, aedeagus in lateral view, digitus, cuspis, paramere; 2, male genitalia of $N$. championi (Dover). From left to right, aedeagus in ventral view, aedeagus in lateral view, digitus, cuspis, paramere; 3, male genitalia of Chartergellus punctatior Richards. From left to right, aedeagus in ventral view, aedeagus in lateral view, digitus, cuspis, paramere. Setae on the volsellae have been omitted for clarity. Scale bars $=1 \mathrm{~mm}$. 

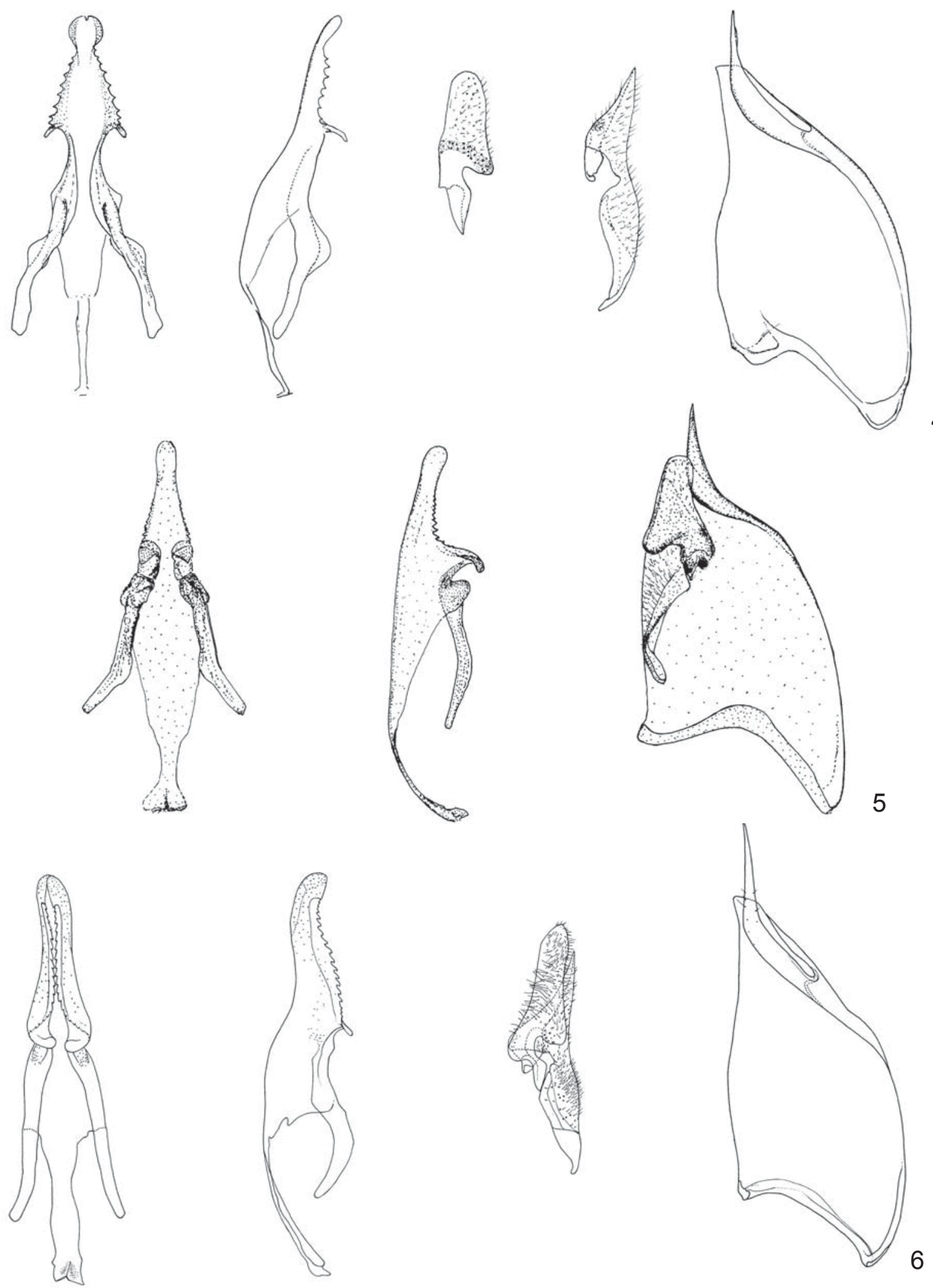

Figs. 4-6. 4, male genitalia of Leipomeles dorsata (Fabricius). From left to right, aedeagus in ventral view, aedeagus in lateral view, digitus, cuspis, paramere. The specimen drawn was from Panama: Bugaba, 800-1500 ft. (Godman-Salvin), determined by Richards, and deposited in the Natural History Museum. No scale was provided; 5, male genitalia of Marimbonda albogrisea Richards. From left to right, aedeagus in ventral view, aedeagus in lateral view, volsella + paramere. The specimen drawn was a paratype; no scale was provided; 6, male genitalia of Parachartergus griseus (Fox). From left to right, aedeagus in ventral view, aedeagus in lateral view, volsella, paramere. No provenance on the specimen was provided, nor scale, but the drawing was stated to have been made at $75 \mathrm{x}$. 

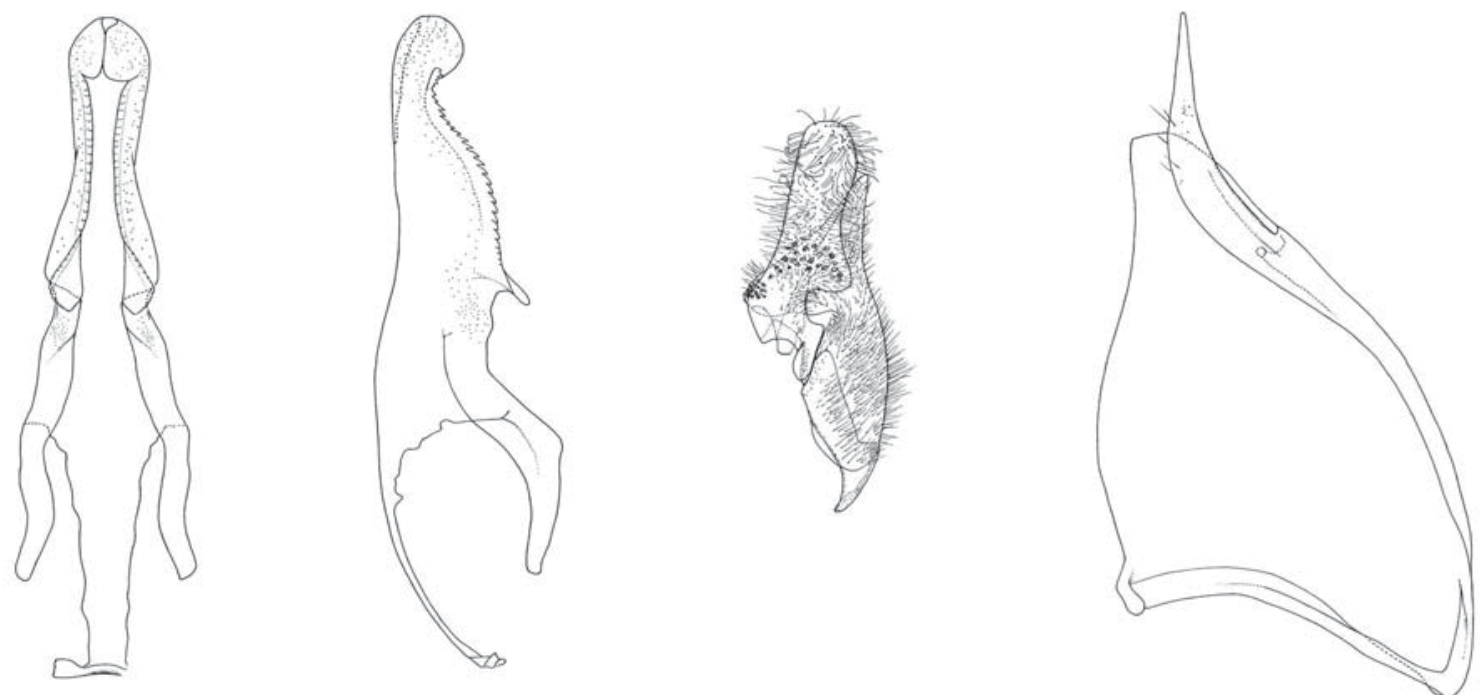

7
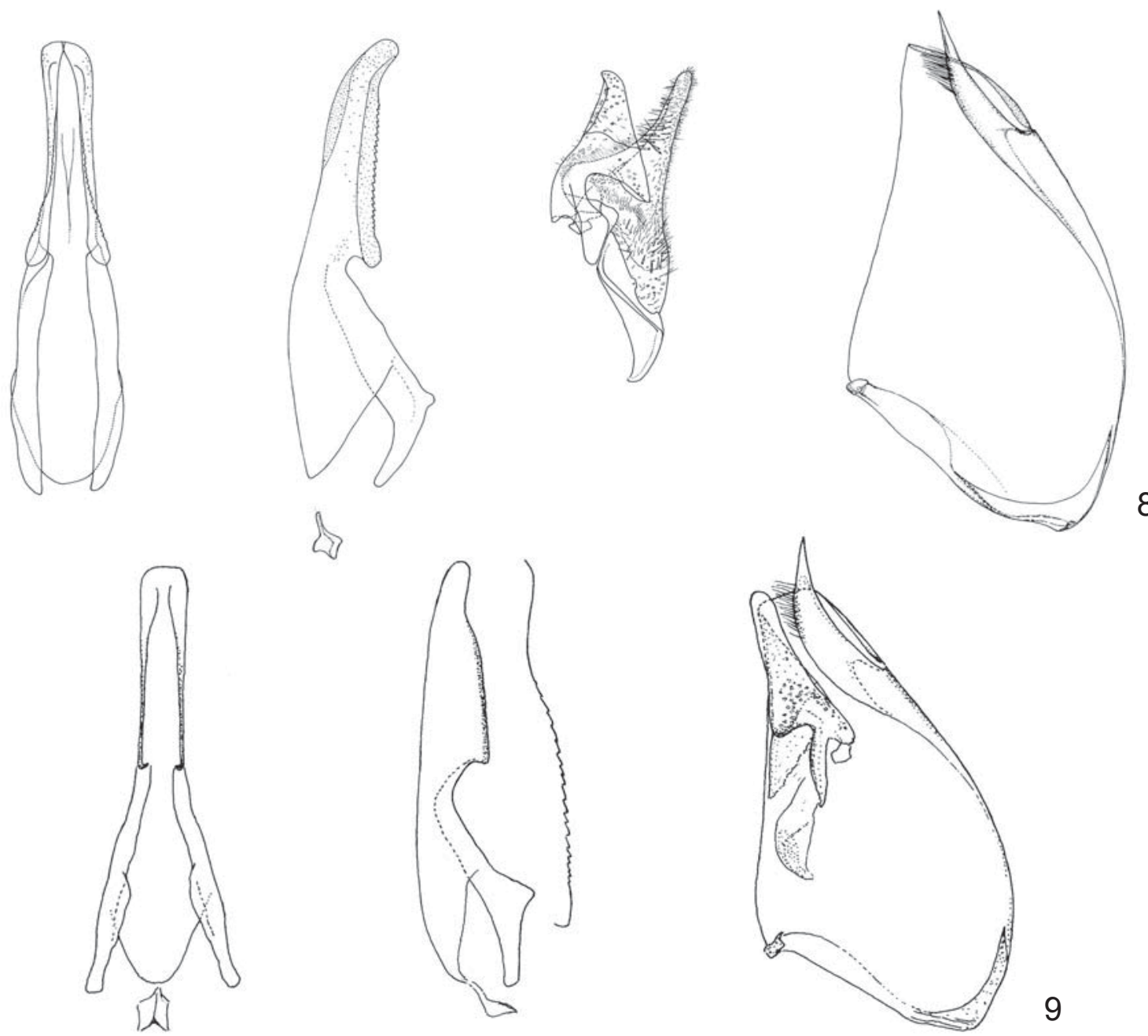

8

Figs. 7-9. 7, male genitalia of Parachartergus apicalis (Fabricius). From left to right, aedeagus in ventral view, aedeagus in lateral view, volsella, paramere. The specimen drawn was from Mexico: Orizaba, March 1975. No scale was provided, but the drawing was stated to have been made at $75 \mathrm{x} ; 8$, male genitalia of Pseudopolybia compressa (de Saussure). From left to right, aedeagus in ventral view, aedeagus in lateral view, volsella, paramere. No provenance on the specimen was provided, nor scale, but the drawing was stated to have been made at $75 \mathrm{x}$, and the following dimensions (presumably length) given: paramere $2.25 \mathrm{~mm}$, aedeagus $2.15 \mathrm{~mm}$, volsella $1.45 \mathrm{~mm}$; 9, male genitalia of Pseudopolybia difficilis (Ducke). From left to right, aedeagus in ventral view, aedeagus in lateral view, closeup of ventral teeth of aedeagus, volsella + paramere. The specimen drawn was from Brazil: Peixe-Boi, June 1909 (E. F. Bragança), determined by Ducke and confirmed by Richards, and deposited in the Natural History Museum. No scale was provided. 
basal angle on the paramere (Figs. 1-2, 4-7), which may be apomorphic - but in this case, again, Chartergellus (Fig. 3) is more similar to Pseudopolybia (Figs. 8-9) in its obtuse basal angle. The apical angle of the paramere is narrow in Leipomeles (Fig. 4), Parachartergus griseus (Fox, 1898) (Fig. 6), and to some extent Marimbonda (not readily seen in Fig. 5) and $P$. apicalis (Fabricius, 1804) (Fig. 7); the other genera have this angle broad (Figs. 1-3, 8-9). This pattern is not in accord with the relationships mentioned above either, but as the variation is evidently at the level of genera, may be interpretable as homoplastic at this level. Leipomeles (Fig. 4) has a broad angular expansion on the basal apodeme. Marimbonda (Fig. 5) has one as well, but smaller and more posterior (i. e., apical). Pseudopolybia (Figs. 8-9) presents more pointed expansions, placed about as in Leipomeles. Nectarinella (Figs. 1-2) and Chartergellus (Fig. 3) appear to have very small expansions or angles. Parachartergus apicalis (Fig. 7) has a slight expansion - but P. griseus (Fig. 6) has none. As this character appears general in the taxa studied here, it may be apomorphically lost in Parachartergus griseus. RICHARDS (1978) recognized two species groups in Parachartergus, one corresponding to $P$. apicalis and one to $P$. griseus; comparison of additional species is desirable to test whether the inferred loss of the expansion is a group character. Finally, the two species of Pseudopolybia are alike in possessing the small sclerite basad of the aedeagus depicted in Figs. 8-9. This may be a synapomorphy for the genus, but will have to be studied in the two species of the genus not considered here.

Various unique states are also apparent in some of these illustrations. Studies of additional taxa in some of these genera are required to establish, e. g. whether the shape of the ventral process of the aedeagus in Marimbonda albogrisea Richards, 1978 (Fig. 5) is an autapomorphy, or synapomorphy for the genus. It is our hope that this study will stimulate such investigations in the future.

Acknowledgments. Field work that led to the collection of the males of $N$. championi was supported by NSF grant BSR-9006102 to Carpenter. The figures of Nectarinella and Chartergellus were provided by Valerie Giles. We thank Kurt Pickett for comments on the manuscript.

\section{REFERENCES}

Bequaert, J. C. 1938. A new Charterginus from Costa Rica, with notes on Charterginus, Pseudochartergus, Pseudopolybia, Epipona, and Tatua (Hymenoptera, Vespidae). Revista de Entomologia 9(1/ 2): $99-117$.

Dover, C. 1925 (1924). Notes on the genus Nectarina Shuckard (Vespidae). Psyche 31(6): 305-307.

Mateus, S. \& F. B. Noll. 1998 (1997). Nectarinella xavantinensis, a new neotropical social wasp (Hymenoptera: Vespidae; Polistinae). Journal of the New York Entomological Society 105(1/2): 45-49.

Richards, O. W. 1978. The Social Wasps of the Americas, Excluding the Vespinae. London, British Museum (Natural History), v +580 p. +4 pls.

Schremmer, F. 1977. Das Baumrinden-Nest der neotropischen Faltenwespe Nectarinella championi, umgeben von einem Leimring als AmeisenAbwehr (Hymenoptera: Vespidae). Entomologica Germanica 3(4): 344-355.

SкuTch, A. F. 1971. A Naturalist in Costa Rica. Gainesville, University of Florida Press, $\mathrm{x}+382 \mathrm{p}$

Received 16.II.2004; accepted 30.VI.2004 